Metallophysics and Advanced Technologies

Металофіз. новітні технол.

Metallofiz. Noveishie Tekhnol.

2021 , vol. 43 , No. 3 , pp. 407-423

https://doi.org/10.15407/mfint.43.03.0407

Reprints available directly from the publisher
(C) 2021 G. V. Kurdyumov Institute for Metal Physics, National Academy of Sciences of Ukraine Published by license under the G. V. Kurdyumov Institute for Metal PhysicsN.A.S. of Ukraine Publishers imprint. Printed in Ukraine.

PACS numbers: 62.20.Qp, 81.05.Ni, 81.05.Bx, 81.30.Hd, 81.40.Gh, 81.40.Pq

\title{
Regularities of Formation of Structure, Phase Composition and Properties of Chromium-Manganese Alloys in the Initial Cast State during the Process of Friction Wear
}

\author{
Yu. M. Koval, V. Z. Kutsova*, and M. A. Kovzel ${ }^{* *}$ \\ G.V.Kurdyumov Institute for Metal Physics, N.A.S. of Ukraine, \\ 36 Academician Vernadsky Blvd., \\ UA-03142 Kyiv, Ukraine \\ "National Metallurgical Academy of Ukraine, \\ 4 Gagarin Ave., \\ UA-49600 Dnipro, Ukraine \\ * Z. I. Nekrasov Iron and Steel Institute, N.A.S. of Ukraine, \\ 1 Academician Starodubov Sqr., \\ UA-49050 Dnipro, Ukraine
}

Structural and phase transformations, as well as changes in the microhardness of the matrix, austenite-carbide eutectic, and total hardness that occur in chromium-manganese alloys in the cast state during wear by friction under different loads are studied. As shown, a high wear resistance of chromium-manganese alloy $(\mathrm{C}-3.1 \%, \mathrm{Cr}-13.1 \%, \mathrm{Mn}-15.75 \%, \mathrm{Ni}-1.15 \%)$ is associated with high microhardness of the matrix, austenitic-carbide eutectic based on $\mathrm{Me}_{7} \mathrm{C}_{3}$ carbide and determined by the degree of doping and the parameter of the shape of the eutectic carbide, as well as due to the deformation-phase transformations that occur in the investigated alloys during friction wear.

Key words: chromium-manganese alloy, wear resistance, structure, phase composition, hardness, microhardness.

Досліджено структурні та фазові перетворення, а також зміни мікротвердості матриці, аустеніто-карбідної евтектики і загальної твердості, що відбуваються в хромомарганцевих стопах у литому стані в процесі зносу

Corresponding author: Maksim Kovzel

E-mail: kovzel.maxim@gmail.com

Citation: Yu. M. Koval, V. Z. Kutsova, and M. A. Kovzel, Regularities of Formation of Structure, Phase Composition and Properties of Chromium-Manganese Alloys in the Initial Cast State during the Process of Friction Wear, Metallofiz. Noveishie Tekhnol., 43, No. 3: 407-423 (2021), DOI: 10.15407/mfint.43.03.0407. 
тертям при різних навантаженнях. Показано, що висока зносостійкість хромомарганцевого стопу $(\mathrm{C}-3,1 \%, \mathrm{Cr}-13,1 \%, \mathrm{Mn}-15,75 \%, \mathrm{Ni}-$ $1,15 \%$ ) пов'язана з високою мікротвердістю матриці, аустеніто-карбідної евтектики на базі карбіду $\mathrm{Me}_{7} \mathrm{C}_{3}$ та визначається ступенем леґованості $\mathrm{i}$ параметром форми евтектичного карбіду, а також обумовлена деформаційно-фазовими перетвореннями, що відбуваються в досліджених стопах в процесі зносу тертям.

Ключові слова: хромомарганцевий стоп, зносостійкість, структура, фазовий склад, твердість, мікротвердість.

(Received October 22, 2020; in final version, January 27, 2021)

\section{INTRODUCTION}

Metallurgical and machine-building industries are one of the largest industries in Ukraine and the world. The development of these industries contributes to a significant increase in the country's GDP and improved economic ties with other countries through the export of manufactured products. The world metallurgical and machinebuilding industries are developing dynamically and require the use of modern functional materials with an increased set of tribological properties for the manufacture of machine parts and products that wear out quickly and have low operational stability. The solution of these problems is directly related to increasing the complex of tribological properties of functional materials, in particular, high-chromium and chromium-manganese alloys.

Nowadays, high-chromium and chromium-manganese alloys are widely used in industry. Parts of these alloys work in conditions of abrasive, shock-abrasive wear and friction wear both at room and at elevated temperatures [1-4]. They are used to make rolling tools (mandrels, dies, rulers, etc.) and mechanical engineering products (rolling rolls, blades of shot blasting machines, armour plates of mills and grinding bodies).

Mechanical and tribological properties of economically alloyed highchromium and chromium-manganese alloys are determined by the phase composition and structure of the metal base, quantity, type and structure of carbide phases, as well as metastability of austenite, which undergoes deformation phase transformations in surface layers during operation. The formation of bainitic nanostructure in the surface layers and the development of deformation phase transformations fundamentally distinguishes these alloys from those known with a stable structure and provides improved mechanical and operational properties.

Analysis of domestic and foreign literature showed that information on the relationships of composition, type of matrix, mechanical properties and wear resistance of high chromium and chromium-mangane- 
se alloys is virtually absent in the modern metallurgical literature [510].

In this regard, the study of structural and phase changes in the process of tribological tests in chromium-manganese alloys in the initial cast state is an urgent task of modern materials science in terms of improving the performance of rolling tools and engineering products.

\section{MATERIAL AND METHODS OF RESEARCH}

To conduct studies of phase and structural transformations in the solid state in chromium-manganese alloys, experimental melts were smelted in industrial conditions. The calculation of the charge was performed on the main alloying elements for this type of alloys-carbon, chromium and manganese. The chemical composition of the experimental alloys are shown in Table 1.

Friction tests for wear of chromium-manganese-nickel alloys in the cast state were performed at elevated $\left(950^{\circ} \mathrm{C}\right)$ temperatures at the modernized friction unit 2070 CMT-1, according to the 'shaft-plane' scheme [11]. Samples in the form of a parallelepiped, dimensions $10 \times 10 \times 27 \mathrm{~mm}^{3}$ were used for tests. As a counterbody used Article 45 . At elevated test temperature, the samples were placed on a special mandrel, created a load of $500 \mathrm{~N}$, and heated by friction at a sliding speed of $2 \mathrm{~m} / \mathrm{s}$. for one minute the contact temperature reached $950^{\circ} \mathrm{C}$, the temperature was measured by pyrometric method.

The microstructure of the experimental samples of chromiummanganese alloys in the initial state and after wear by friction was detected in a $10 \%$ alcoholic solution of nitric acid. Microstructure studies were performed using the 'Neophot-21' optical microscope and a JSM-35 scanning electron microscope.

Determination of the number of phases and structural components in the structure of the experimental alloys was performed by the method of A. A. Glagolev at magnification $\times 400$ [12].

Phase identification in the experimental chromium-manganese alloys was performed by X-ray diffraction analysis on a DRON-3M diffractometer in $\mathrm{Cu} K_{\alpha}$ radiation. To determine the lattice parameter of unconverted austenite, the profile of diffraction maxima $(111)_{\gamma},(002)_{\gamma}$, (113) $\gamma$ was recorded on three mutually perpendicular sides of the sample, and each side was recorded five times at a rate of $(1 / 8)^{\circ} / \mathrm{min}$.

The lattice parameter was calculated from the position of the centre of mass of the above diffractometric maxima. The obtained results were subjected to statistical processing according to standard methods. The amount of residual austenite was determined from the ratio of the integrated intensities of lines (001) (and (111)) [13].

The microhardness of the phases and structural components was determined using a microhardness tester PMT-3 according to standard 
TABLE 1. Chemical composition of the experimental chromium-manganese alloys.

\begin{tabular}{c|c|c|c|c|c|c|c|c|c|c}
\hline \multirow{2}{*}{ No. } & \multicolumn{10}{|c}{ The content of alloying elements, \% } \\
\cline { 2 - 12 } & $\mathrm{C}$ & $\mathrm{Cr}$ & $\mathrm{Ni}$ & $\mathrm{V}$ & $\mathrm{Mn}$ & $\mathrm{Si}$ & $\mathrm{Cu}$ & $\mathrm{S}$ & $\mathrm{P}$ & $\mathrm{Fe}$ \\
\hline 1 & 2.2 & 12.63 & 0.83 & 0.25 & 5.7 & 1.0 & 0.10 & 0.009 & 0.013 & 77.3 \\
2 & 2.7 & 15.91 & 0.95 & 0.25 & 10.5 & 0.9 & 0.9 & 0.009 & 0.027 & 67.9 \\
3 & 3.1 & 13.1 & 1.15 & 0.25 & 15.75 & 0.9 & 0.15 & 0.003 & 0.025 & 65.57 \\
\hline
\end{tabular}

methods. The hardness of chromium-manganese alloys in the cast state and after wear by friction was determined by the Rockwell method according to standard methods.

\section{RESEARCH RESULTS}

The friction wear tests at high temperatures and loads of samples of experimental chromium-manganese alloys in the initial cast state are carried out in the work. Table 2 and Fig. 1 show the results of friction wear tests of chromium-manganese alloys in the cast state.

Analysis of the data in Table 2 and Fig. 1 shows that the alloy 3 is characterized by the highest wear resistance (minimum wear intensity and high coefficient of wear resistance) as a result of wear by friction at elevated temperatures.

Testing of chromium-manganese alloys in the cast state for wear resistance under friction under different loads leads to phase and structural transformations, as well as to changes in the microhardness of the matrix, austenitic carbide eutectic and the overall hardness of the test samples.

Table 3 shows quantitative data on changes in microhardness and hardness of test samples of chromium-manganese alloys during friction wear at different loads.

Friction wear at different loads leads to an increase in the microhardness of the matrix and austenitic-carbide eutectic of all experimental alloys (Table 3). At the same time, the increase in hardness during wear by friction is observed only in alloy 1 . The hardness of alloys 2 and 3 in the process of wear is practically unchanged.

This nature of the change in microhardness and hardness of the test specimens is associated with structural changes, and is probably due to the redistribution of alloying elements between the phases and structural components in the process of wear and friction.

Figures 2-4 show the microstructures of the experimental chromium-manganese alloys in the initial state and after wear by friction at different loads and temperatures. 
TABLE 2. Test results for wear resistance of chromium-manganese alloys in the cast state.

\begin{tabular}{|c|c|c|c|c|c|c|c|c|}
\hline \multirow[t]{2}{*}{ No. } & \multicolumn{2}{|c|}{$\begin{array}{l}\text { Linear wear, } \\
\text { microns }\end{array}$} & \multicolumn{2}{|c|}{ Volume wear, $\mathrm{cm}^{3}$} & \multicolumn{2}{|c|}{ Wear intensity, $i$} & \multicolumn{2}{|c|}{\begin{tabular}{|c} 
Coefficient of \\
wear resistance, \\
$n$
\end{tabular}} \\
\hline & 5001 & $600 \mathrm{~N}$ & $500 \mathrm{~N}$ & $600 \mathrm{~N}$ & 80018 & $600 \mathrm{~N}$ & $500 \mathrm{~N}$ & $600 \mathrm{~N}$ \\
\hline \multicolumn{9}{|c|}{ Alloy No. 1} \\
\hline 1 & 628 & 568 & 0.05092 & 0.12705 & $2.33 \cdot 10^{-7}$ & $5.81 \cdot 10^{-7}$ & 6.63 & 6.24 \\
\hline 2 & 682 & 622 & 0.05529 & 0.05042 & $2.53 \cdot 1$ & $2.31 \cdot 1$ & 6.59 & .63 \\
\hline 3 & 299 & 145 & 0.02429 & 0.11631 & 1.11 & $5.32 \cdot 1$ & ( & .27 \\
\hline 4 & 327 & 232 & 0.026562 & 502 & 1.2 & $1.60 \cdot 10^{-7}$ & 91 & .79 \\
\hline 5 & 321 & 118 & 0.02606 & 0.08946 & 1.19 & $4.09 \cdot 10^{-7}$ & 6.92 & .39 \\
\hline 6 & 296 & 218 & 0.02 & .12589 & 1.10 . & 5.7 & & .24 \\
\hline \multicolumn{9}{|c|}{ Alloy No. 2} \\
\hline 7 & 178 & 64 & 0.0 & 0.01329 & $6.61 \cdot 10^{-8}$ & $6.08 \cdot 10^{-8}$ & 7.17 & .22 \\
\hline 8 & 216 & 281 & 0.01756 & 0.02276 & $8.03 \cdot 10^{-8}$ & $1.04 \cdot 10^{-8}$ & 7.09 & 6.98 \\
\hline 9 & 203 & 137 & 0.01645 & 0.01116 & 7.52 & $5.11 \cdot 10^{-8}$ & 7.12 & .29 \\
\hline 10 & 25 & 17 & 0. & & 9.5 & $6.61 \cdot 10^{-8}$ & 7.02 & .18 \\
\hline 11 & 253 & 14 & 0.0 & 0.0 & 9.3 & $5.38 \cdot 10^{-8}$ & 7.02 & 7.27 \\
\hline 12 & 248 & 231 & 0.02009 & 0.01871 & $9.19 \cdot 10^{-8}$ & $8.56 \cdot 10^{-8}$ & 7.03 & 7.08 \\
\hline \multicolumn{9}{|c|}{ Alloy No. 3} \\
\hline 13 & 153 & 110 & 0.01 & 0.00 & $5.7 \cdot 10^{-8}$ & $4.09 \cdot 10$ & 7.24 & 7.34 \\
\hline 14 & 169 & 152 & 0.01373 & 0.01232 & $6.2 \cdot 10^{-8}$ & $5.64 \cdot 10^{-8}$ & 7.20 & 7.25 \\
\hline 15 & 175 & 212 & & 0.01718 & $6.51 \cdot 10^{-8}$ & $7.86 \cdot 10^{-8}$ & 7.18 & 7.11 \\
\hline 16 & 165 & 166 & 0.01 & 0.01346 & $6.11 \cdot 10^{-8}$ & $6.16 \cdot 10^{-8}$ & 7.21 & 7.21 \\
\hline 17 & 220 & 196 & 0.01782 & 0.01594 & $8.15 \cdot 10^{-8}$ & $7.29 \cdot 10^{-8}$ & 7.08 & 7.14 \\
\hline 18 & 163 & 155 & 0.01323 & 0.01768 & $6.05 \cdot 10^{-8}$ & $8.09 \cdot 10^{-8}$ & 7.21 & 7.09 \\
\hline
\end{tabular}

Analysis of the microstructure of experimental samples of alloys in the cast state (Figs. 2-4, $a, b$ ) shows that crystallization begins with the release of dendrites of primary austenite and ends with the formation of eutectic colonies $\mathrm{A}+\mathrm{Cr}_{7} \mathrm{C}_{3} . \mathrm{Me}_{7} \mathrm{C}_{3}$ carbides in both longitudinal and cross-section and finely differentiated austenitic-carbide eutectic based on $\mathrm{Me}_{7} \mathrm{C}_{3}$ carbide are observed in the microstructure [14]. Friction wear at different loads (Figs. 2-4,c-f) leads to the fact that austenite is stabilized and does not undergo martensitic transformation. Traces of deformation in the form of shear lines are also observed in the areas of austenite.

The phase composition of the experimental chromium-manganese 
alloys was studied by X-ray diffraction analysis.

Figures 5-9 show diagrams of diffraction patterns of experimental chromium-manganese alloys in the cast state before and after friction
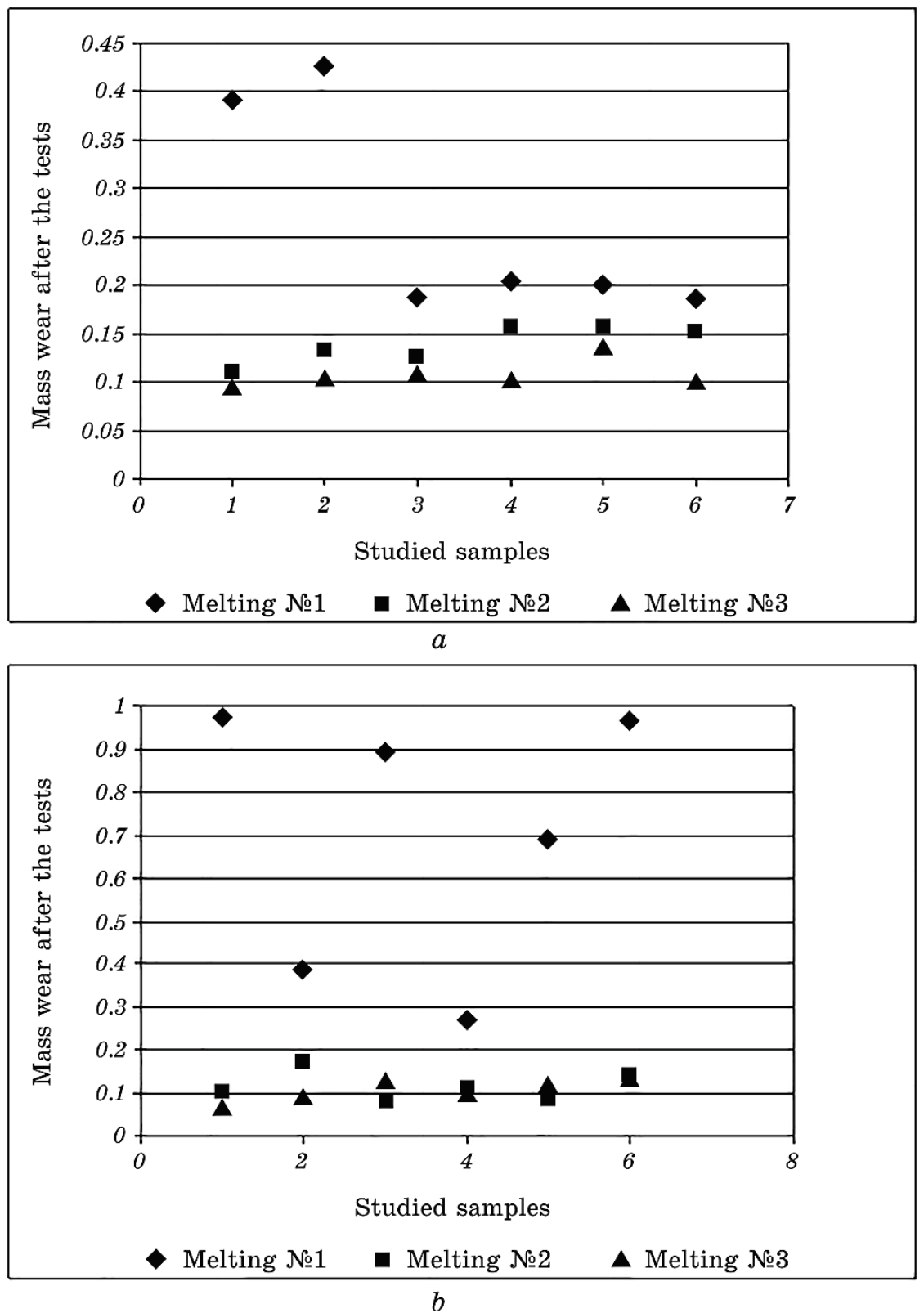

Fig. 1. Mass wear of chromium-manganese alloys in the cast state as a result of friction wear tests: $a$-at a load of $500 \mathrm{~N} ; b$ - at a load of $600 \mathrm{~N}$. 
TABLE 3. Quantitative data on changes in microhardness and hardness of prototypes of chromium-manganese alloys in the process of wear by friction at different loads.

\begin{tabular}{|c|c|c|c|c|c|c|}
\hline \multirow[t]{2}{*}{ No. } & \multicolumn{2}{|c|}{$\begin{array}{l}\text { Microhardness of } \\
\text { the matrix, MPa }\end{array}$} & \multicolumn{2}{|c|}{$\begin{array}{c}\text { Microhardness A-K } \\
\text { eutectic, MPa }\end{array}$} & \multicolumn{2}{|c|}{$\begin{array}{l}\text { Hardness, } \\
\text { HRC }\end{array}$} \\
\hline & $500 \mathrm{~N}$ & $600 \mathrm{~N}$ & $500 \mathrm{~N}$ & $600 \mathrm{~N}$ & $500 \mathrm{~N}$ & $600 \mathrm{~N}$ \\
\hline \multicolumn{7}{|c|}{ Melting No. 1} \\
\hline Before wear & \multicolumn{2}{|c|}{4137} & \multicolumn{2}{|c|}{7920} & \multicolumn{2}{|c|}{35} \\
\hline 1 & 6125 & 5919 & 9737 & 9737 & 41 & 41 \\
\hline 2 & 6342 & 7335 & 10643 & 11681 & 42 & 41 \\
\hline 3 & 5537 & 5537 & 9327 & 8582 & 40 & 41 \\
\hline 4 & 6570 & 6811 & 9737 & 10175 & 41 & 41 \\
\hline 5 & 6125 & 6125 & 9737 & 9737 & 40 & 41 \\
\hline 6 & 4877 & 6811 & 9737 & 10175 & 41 & 40 \\
\hline $\begin{array}{c}\text { Average values after } \\
\text { wear }\end{array}$ & 5930 & 6423 & 9820 & 10015 & 41 & 41 \\
\hline \multicolumn{7}{|c|}{ Melting No. 2} \\
\hline Before wear & \multicolumn{2}{|c|}{4228} & \multicolumn{2}{|c|}{8934} & \multicolumn{2}{|c|}{42} \\
\hline 7 & 5723 & 6811 & 8943 & 11144 & 42 & 42 \\
\hline 8 & 5360 & 7066 & 8943 & 10643 & 43 & 44 \\
\hline 9 & 6125 & 5723 & 11144 & 10643 & 41 & 42 \\
\hline 10 & 6125 & 5919 & 9327 & 10175 & 43 & 43 \\
\hline 11 & 4730 & 4877 & 8241 & 8241 & 42 & 40 \\
\hline 12 & 5919 & 5723 & 8943 & 9327 & 42 & 40 \\
\hline $\begin{array}{l}\text { Average values after } \\
\text { wear }\end{array}$ & 5665 & 6020 & 9256 & 10028 & 42 & 42 \\
\hline \multicolumn{7}{|c|}{ Melting No. 3} \\
\hline Before wear & \multicolumn{2}{|c|}{4663} & \multicolumn{2}{|c|}{9195} & \multicolumn{2}{|c|}{42} \\
\hline 13 & 5030 & 4877 & 12878 & 10643 & 42 & 41 \\
\hline 14 & 5919 & 6811 & 11144 & 10643 & 42 & 43 \\
\hline 15 & 5360 & 5723 & 11144 & 10643 & 43 & 42 \\
\hline 16 & 4730 & 5360 & 11144 & 10643 & 42 & 41 \\
\hline 17 & 5537 & 4730 & 9737 & 9327 & 40 & 42 \\
\hline 18 & 5723 & 5723 & 11144 & 11144 & 42 & 41 \\
\hline $\begin{array}{l}\text { Average values after } \\
\text { wear }\end{array}$ & 5385 & 5540 & 11200 & 10507 & 42 & 42 \\
\hline
\end{tabular}

wear tests at loads of 500 and $600 \mathrm{~N}$.

$\mathrm{X}$-ray diffraction analysis in experimental alloys revealed carbide $\mathrm{Me}_{7} \mathrm{C}_{3}-(\mathrm{Cr}, \mathrm{Mn}, \mathrm{Fe})_{7} \mathrm{C}_{3}$ [15-19], cementite, austenite and ferrite. 4.

Quantitative data of X-ray diffraction analysis are shown in Table 
The amount of austenite in the matrix of experimental alloys in the initial cast state increase from $87 \%$ to $94 \%$ with increasing content of carbon and alloying elements (chromium and manganese), and ferritedecreases, respectively, from $13 \%$ to $6 \%$ (Table 4 ). The presence of fer-

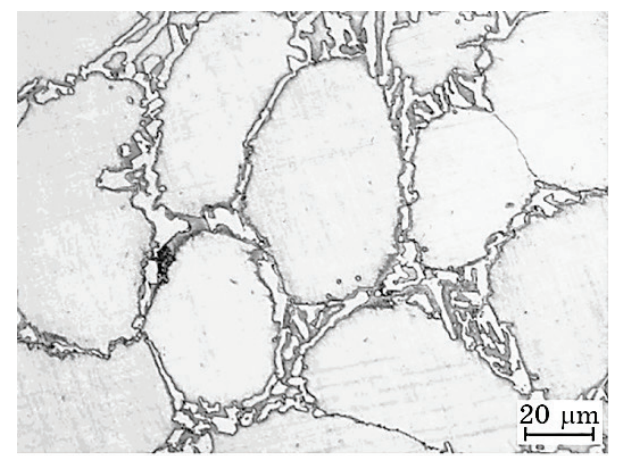

$a$

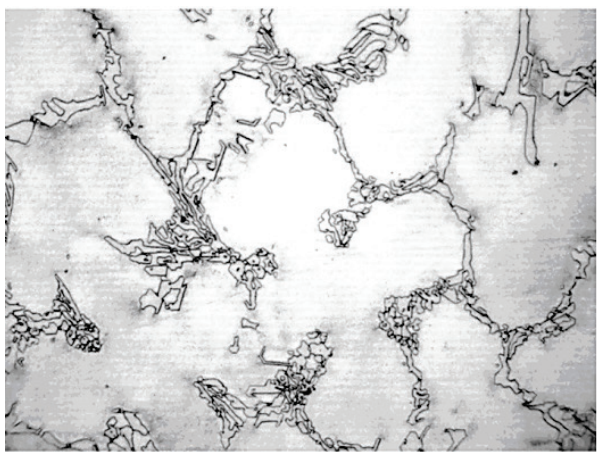

$c$

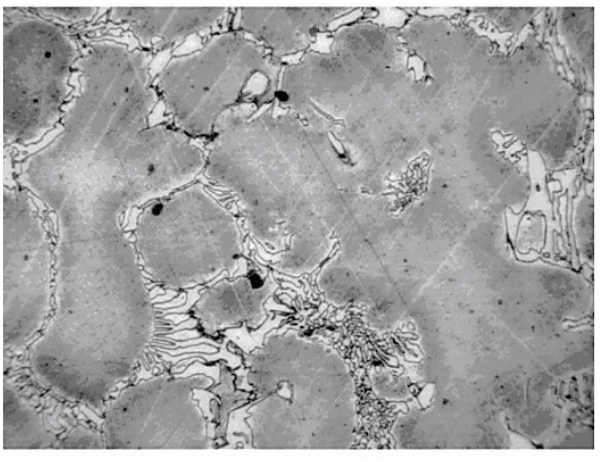

$e$

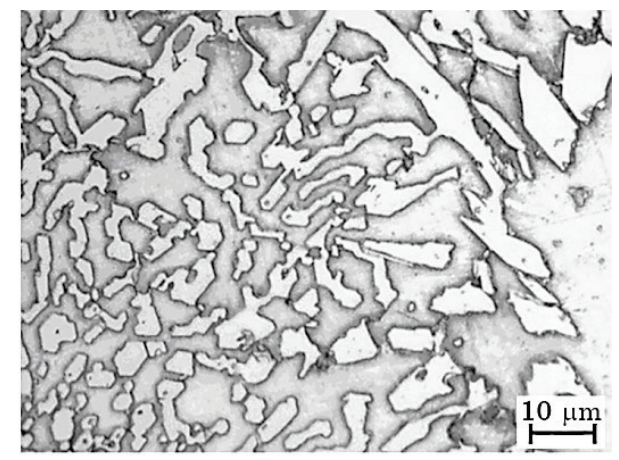

$b$
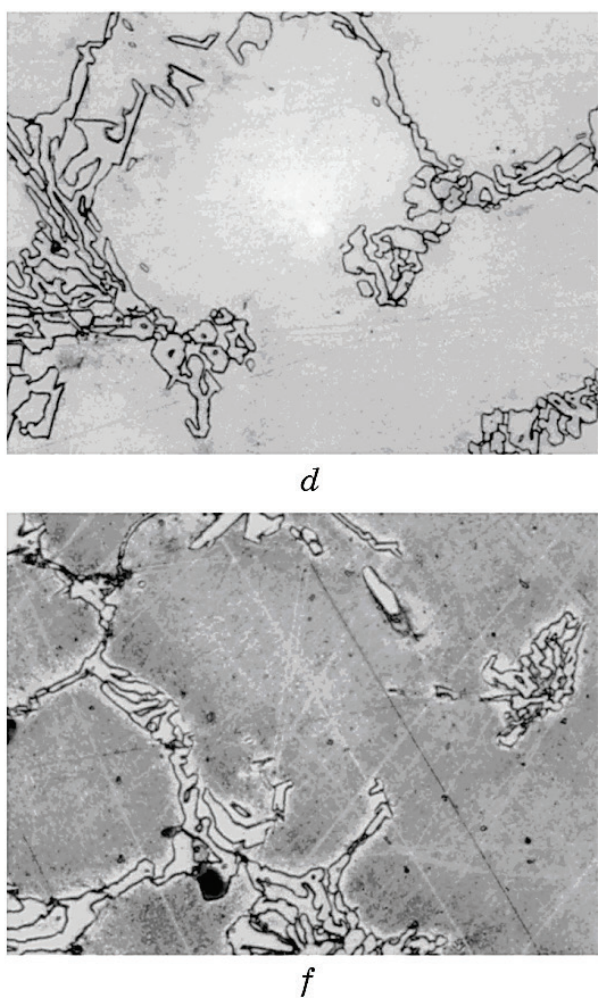

Fig. 2. Microstructure of chromium-manganese alloy in the cast state and after wear by friction at a load of 500 and $600 \mathrm{~N}$ (alloy 1): $a, b$-in the initial cast state; $c, d$-after wear by friction at a load of $500 \mathrm{~N} ; e, f$-after wear by friction at a load of $600 \mathrm{~N}(a, c, b-\times 500 ; b, e, f-\times 1000)$. 
rite is probably due to the insufficient stability of austenite, which undergoes decomposition into ferrite and carbide during cooling.

In the process of friction wear at different loads of experimental alloys there is an increase in the amount of austenite in the matrix of
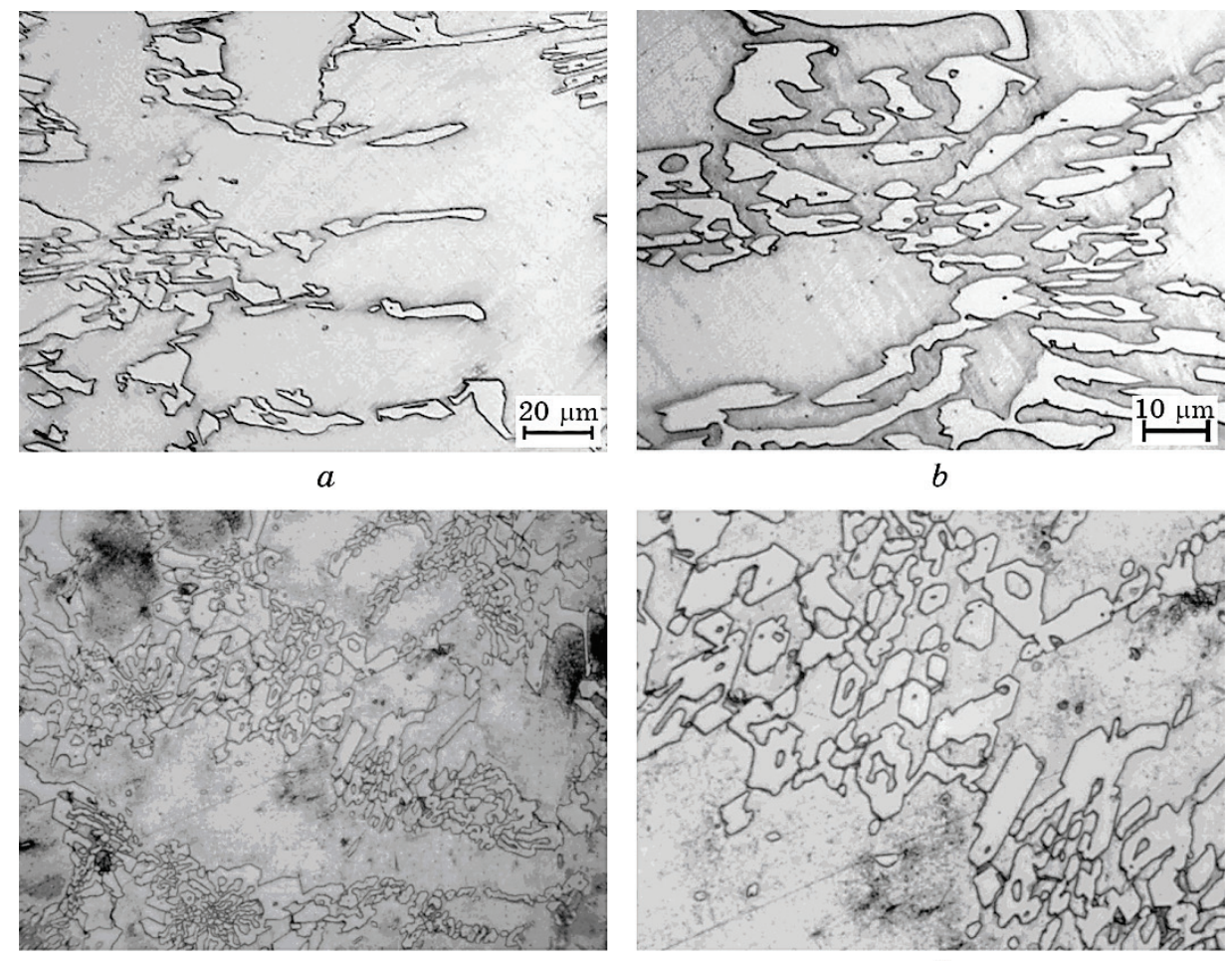

$c$

$d$
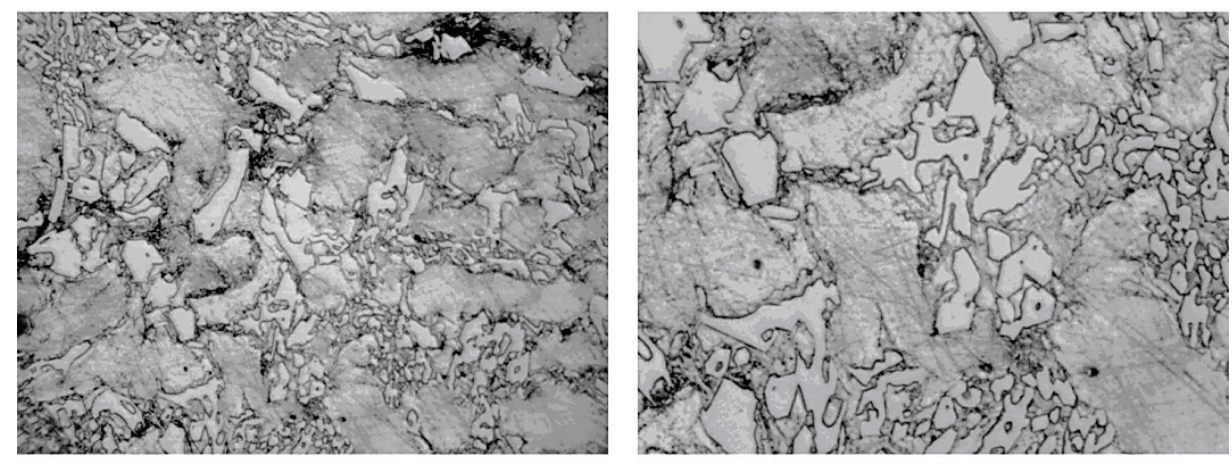

$f$

Fig. 3. Microstructure of chromium-manganese alloy in the cast state and after wear by friction at a load of 500 and $600 \mathrm{~N}$ (alloy 2): $a, b$-in the initial cast state; $c, d$-after wear by friction at a load of $500 \mathrm{~N} ; e, f$-after wear by friction at a load of $600 \mathrm{~N}(a, c, g-\times 500 ; b, g, e-\times 1000)$. 
chromium-manganese alloy 1 from $87 \%$ to $95 \%$, and a decrease in the amount of austenite in the matrix of chromium-manganese alloys 2,3 (alloy 2-decrease in austenite from $92 \%$ to 88 ; alloy 3 -from $94 \%$ to $83 \%$ ) (Table 4 ).

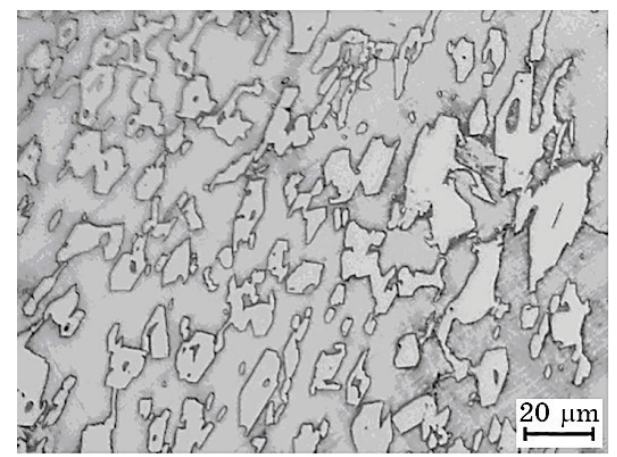

$a$

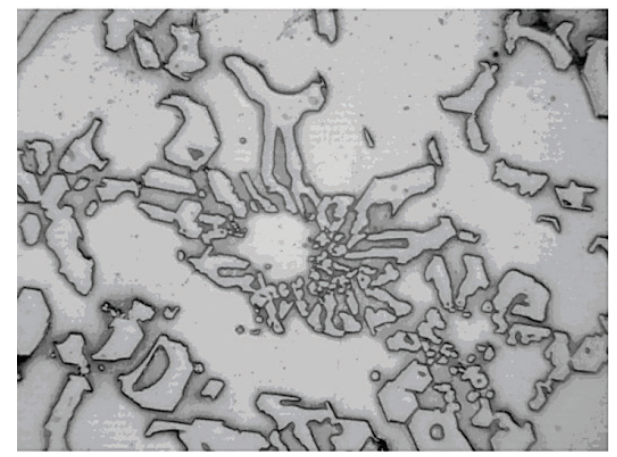

$c$

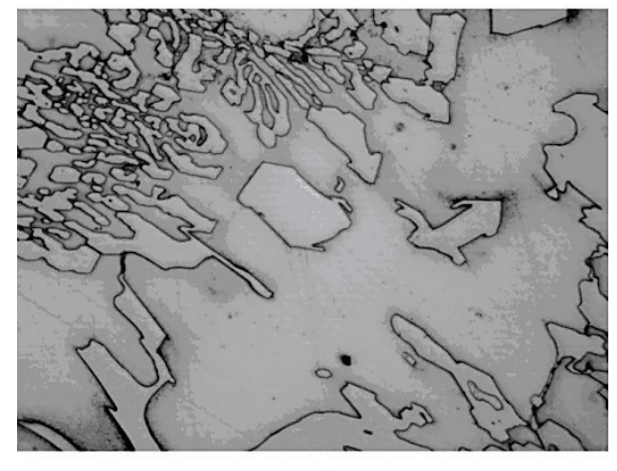

$e$

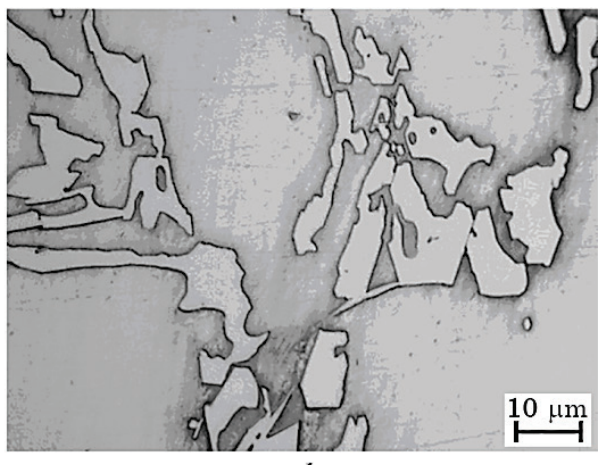

$b$

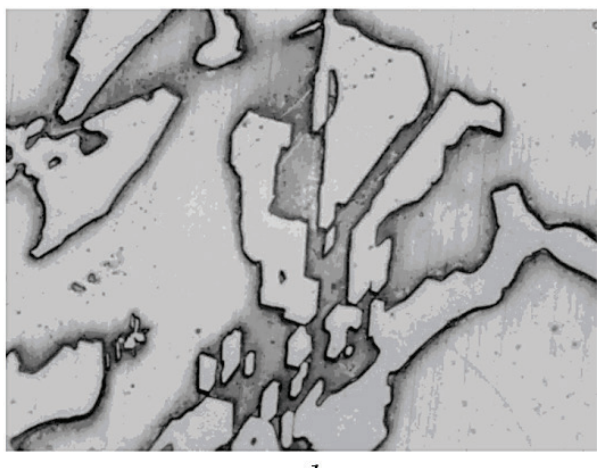

$d$

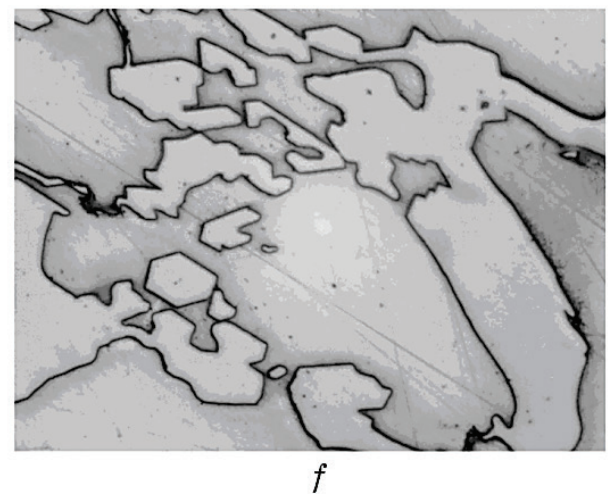

Fig. 4. Microstructure of chromium-manganese alloy in the cast state and after wear by friction at a load of 500 and $600 \mathrm{~N}$ (alloy 3): $a, b$-in the initial cast state; $c, d$-after wear by friction at a load of $500 \mathrm{~N} ; e, f$-after wear by friction at a load of $600 \mathrm{~N}(a, c, d-\times 500 ; b, d, f-\times 1000)$. 
Analysis of the data in Table 4 shows that in the structure of chromium-manganese alloys in the initial cast state there is almost equilibrium $\alpha$-phase, the degree of imperfection $\left(\beta_{0.5}\right)$ of the lattice is in the range from 0.57 to 0.59 , the lattice parameter $\alpha$-phase $\left(a_{\alpha}\right)$ ranges from 2.87 to 2.88. Friction wear of the experimental alloys in all cases leads to an increase in the degree of imperfection of the $\alpha$-phase $\left(\beta_{0.5}\right)$ from 0.57 to 0.69 , the lattice parameter $\alpha$-phase $\left(a_{\alpha}\right)$ ranges from 2.86 to 2.88 .

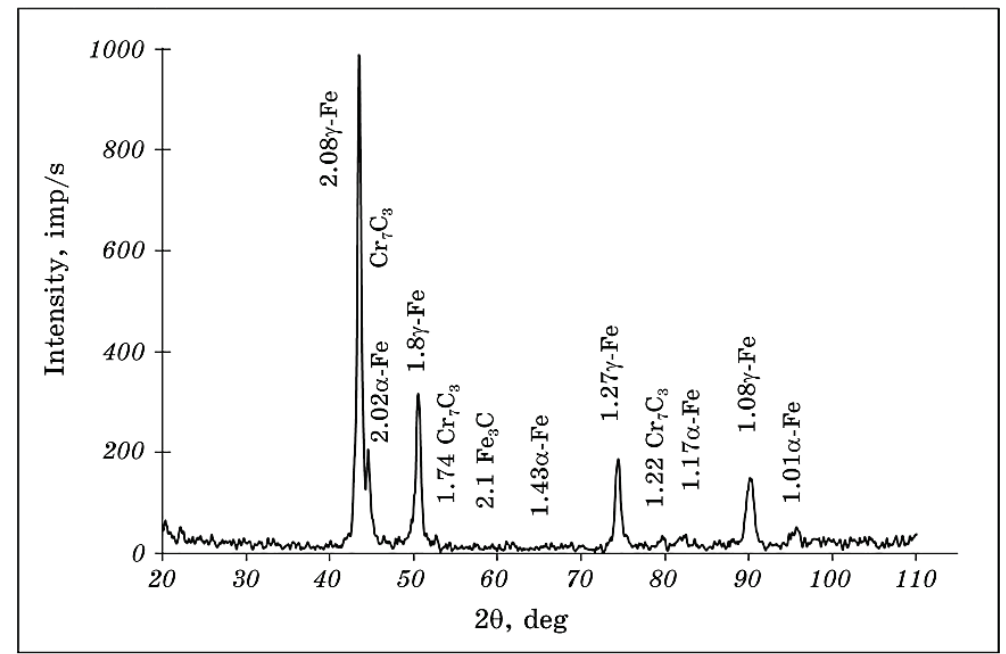

$a$

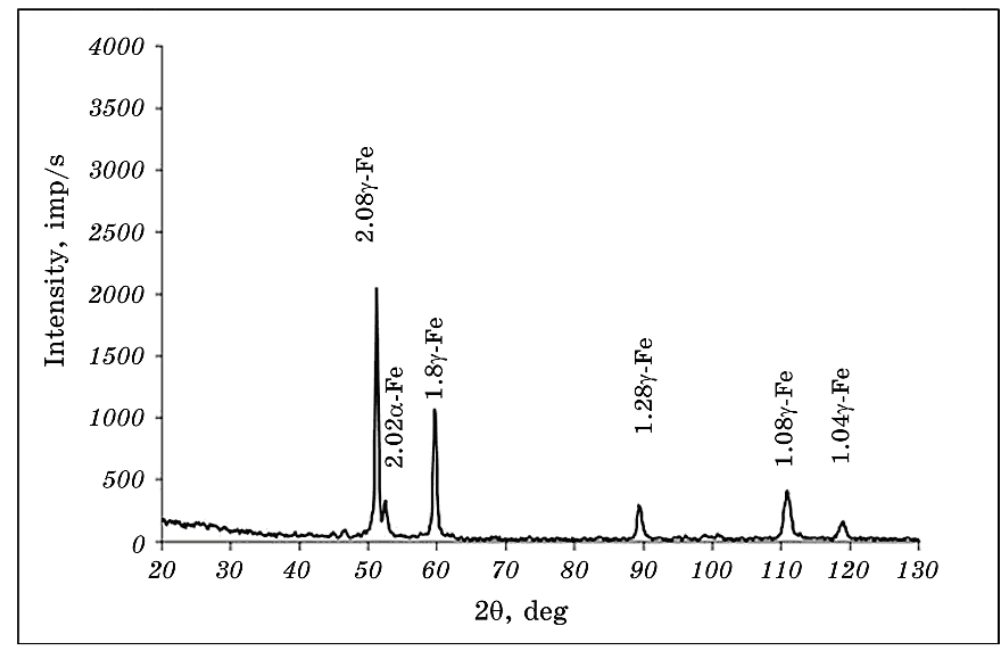

Fig. 5. Diagrams of diffraction patterns of chromium-manganese alloy No. 1 in the cast state before and after friction wear tests at different loads: $a$-in the cast state; $b$-after wear tests by friction at a load of $500 \mathrm{~N}$. 
Phase and structural transformations that occur in the process of wear by friction at different loads are probably related to the redistribution of alloying elements between the phases and structural components of the experimental alloys.

Thus, the high wear resistance of chromium-manganese alloy 3 is

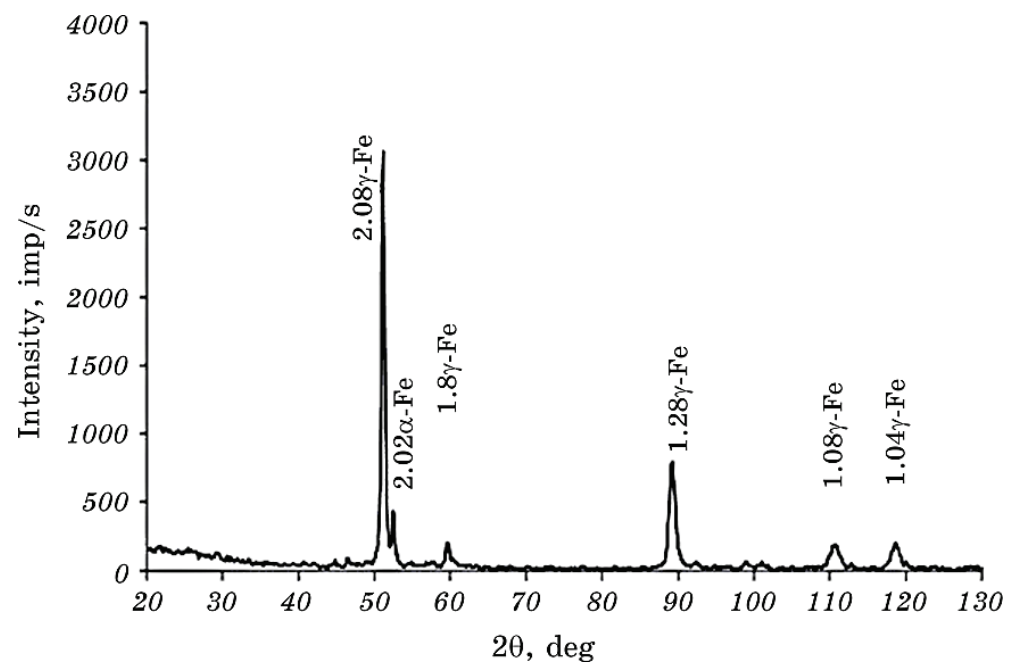

Fig. 6. Diagram of the diffraction pattern of chromium-manganese alloy No. 1 in the initial cast state after wear tests by friction at a load of $600 \mathrm{~N}$.

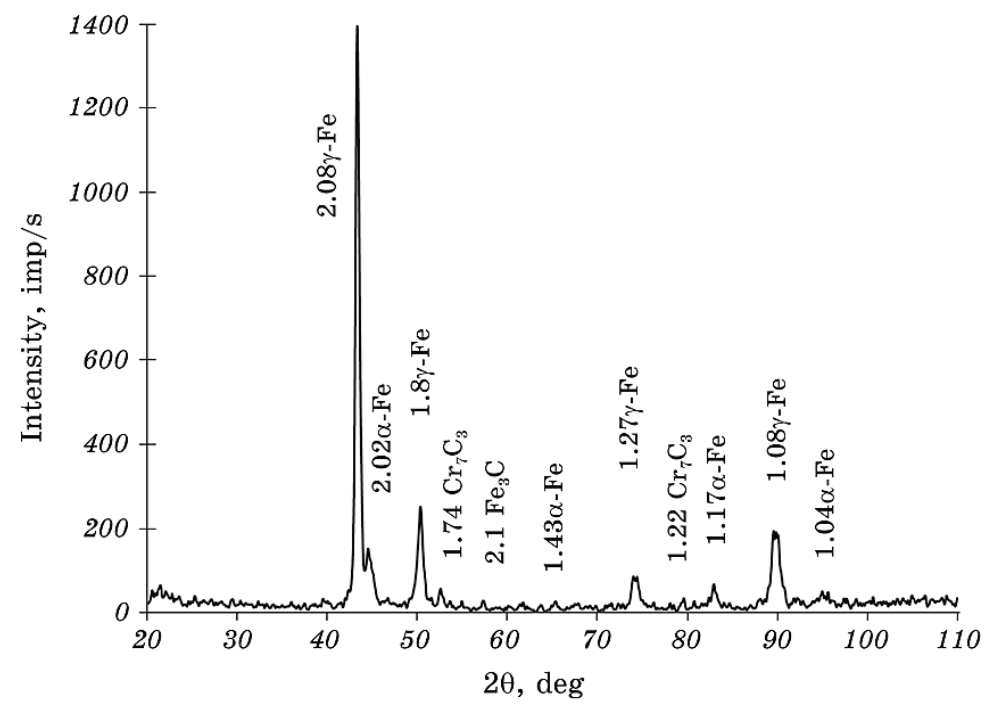

Fig. 7. Diagram of the diffraction pattern of chromium-manganese alloy No. 2 in the initial cast state. 
due to the high microhardness of the matrix, austenitic-carbide eutectic based on carbide $\mathrm{Me}_{7} \mathrm{C}_{3}$ and is determined by the degree of doping and shape parameter of eutectic carbide [20, 21], as well as deformation-phase transformations friction wear.

\section{CONCLUSION}

1. The paper tests for wear resistance under conditions of friction at elevated temperatures and different loads of chromium-manganese alloys in the cast state. It is shown that alloy $3(\mathrm{C}-3.1 \%, \mathrm{Cr}-13.1 \%$,

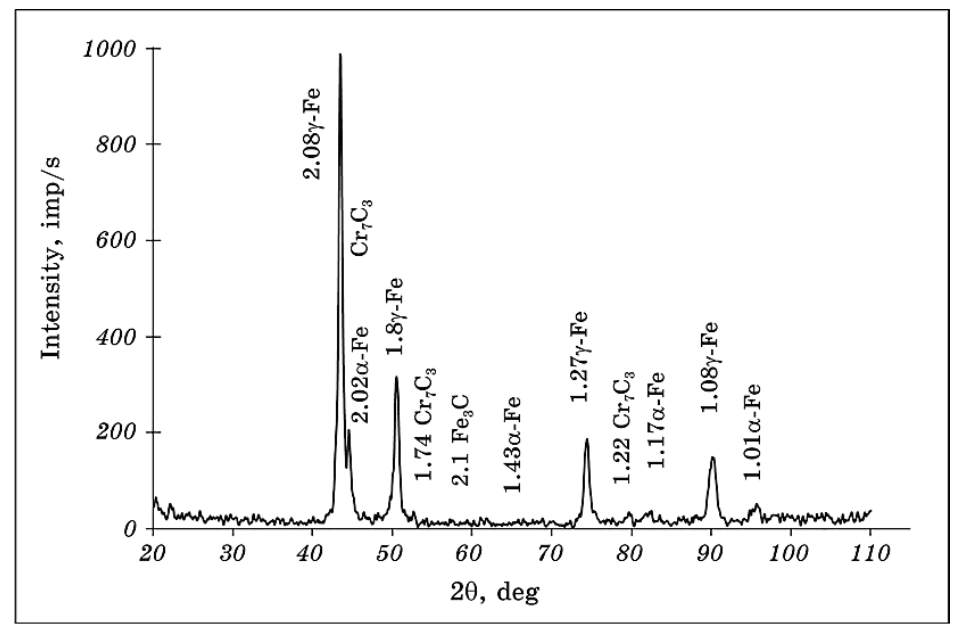

$a$

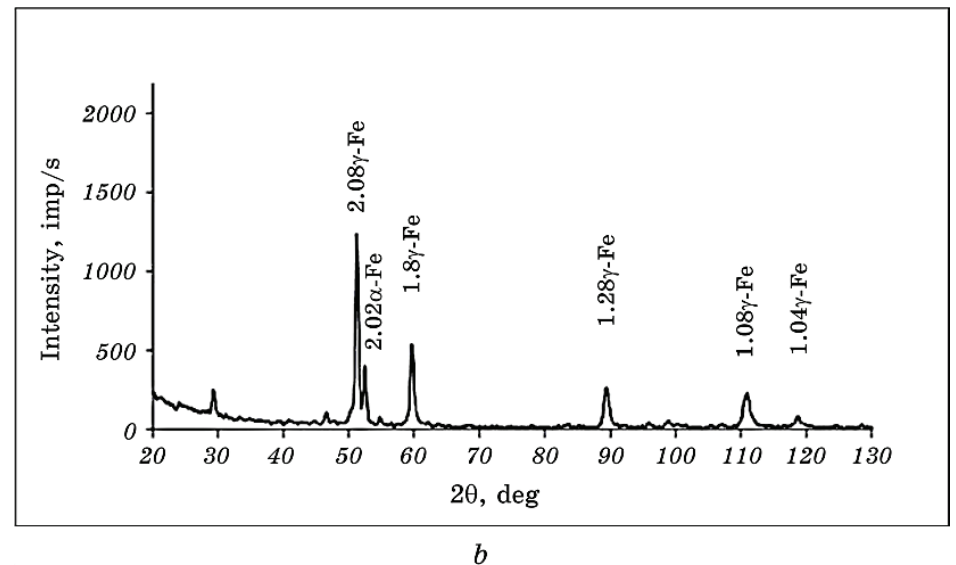

Fig. 8. Diagrams of the diffraction patterns of the alloy No. 2 in the cast state after friction wear tests at different loads: $a$-after friction wear tests at a load of $500 \mathrm{~N} ; b$-after wear tests by friction at a load of $600 \mathrm{~N}$. 
$\mathrm{Mn}-\mathbf{1 5 . 7 5} \%, \mathrm{Ni}-\mathbf{1 . 1 5} \%$ ) is characterized by the highest wear resistance (minimum wear intensity and high coefficient of wear resistance) as a result of tests on friction wear at elevated temperatures and loads of 500 and $600 \mathrm{~N}$.

2. Structural and phase transformations, as well as changes in the mi-

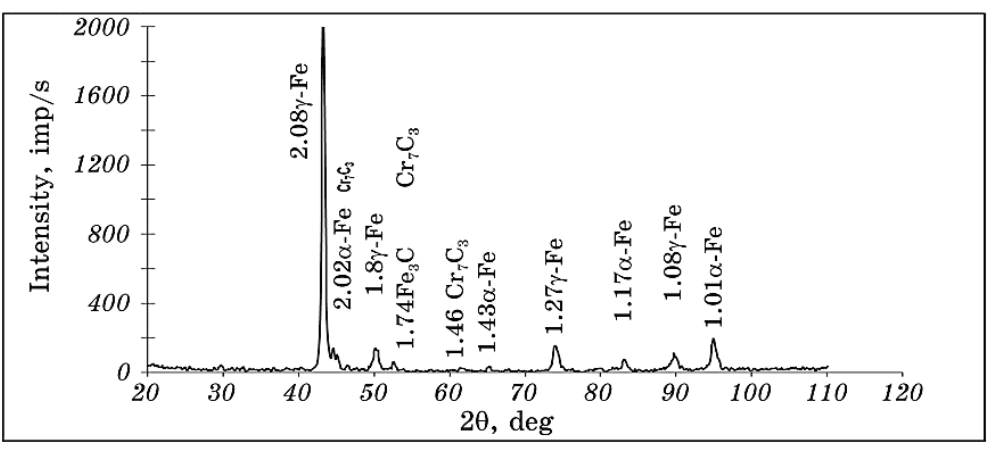

$a$

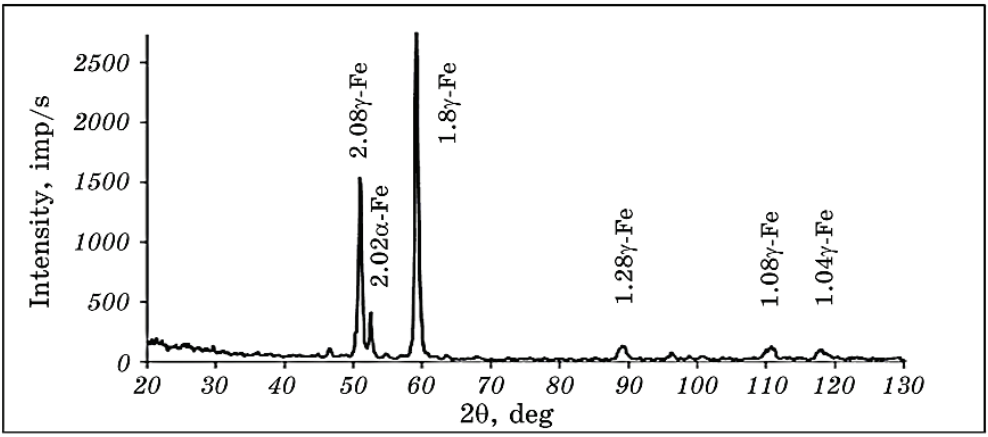

$b$

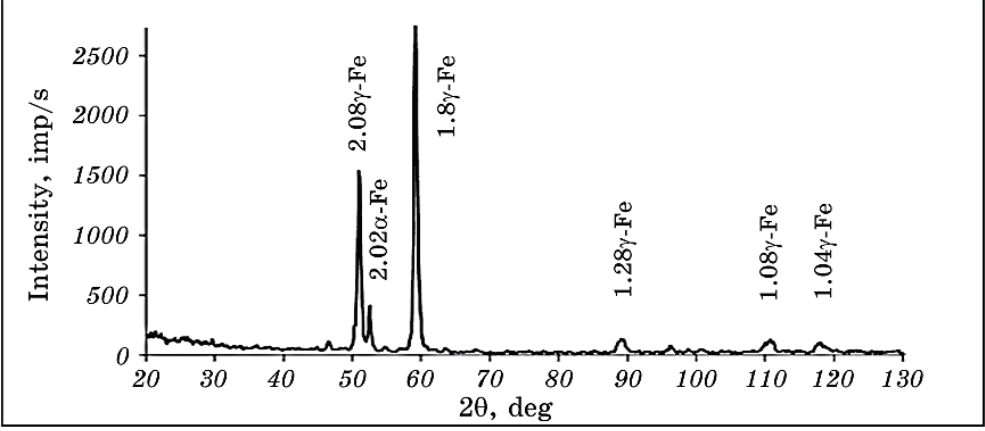

$c$

Fig. 9. Diagrams of diffraction patterns of chromium-manganese alloy No. 3 in the cast state before and after friction wear tests at different loads: $a$-in the cast state; $b$-after wear tests by friction at a load of $500 \mathrm{~N} ; c$-after tests for wear by friction at a load of $600 \mathrm{~N}$. 
TABLE 4. Quantitative data of X-ray diffraction analysis of chromiummanganese alloys in the cast state before and after friction wear tests at different loads.

\begin{tabular}{|c|c|c|c|c|c|c|}
\hline \multirow[t]{2}{*}{ No. } & \multicolumn{2}{|c|}{$a_{\gamma}$ to $(022)_{\gamma}, \mathrm{nm}$} & \multicolumn{2}{|c|}{$\begin{array}{c}\text { Degree of imperfec- } \\
\text { tion of } \alpha-\text { phase }\left(\beta_{0.5}\right) \text {, } \\
\text { deg }\end{array}$} & \multicolumn{2}{|c|}{$\begin{array}{c}\text { The amount of } \\
\text { austenite in the } \\
\text { matrix, \% } \gamma\end{array}$} \\
\hline & $500 \mathrm{~N}$ & $600 \mathrm{~N}$ & $500 \mathrm{~N}$ & $600 \mathrm{~N}$ & $500 \mathrm{~N}$ & $600 \mathrm{~N}$ \\
\hline \multicolumn{7}{|c|}{ Melting No. 1} \\
\hline Before wear & \multicolumn{2}{|c|}{0.360} & \multicolumn{2}{|c|}{0.59} & \multicolumn{2}{|c|}{87} \\
\hline 1 & 0.3601 & 0.3611 & 0.688 & 0.708 & 94 & 92 \\
\hline 2 & 0.3596 & 0.3607 & 0.515 & 0.672 & 90 & 91 \\
\hline 3 & 0.3602 & 0.3606 & 0.964 & 0.624 & 98 & 95 \\
\hline 4 & 0.3601 & 0.3611 & 0.688 & 0.708 & 96 & 91 \\
\hline 5 & 0.3598 & 0.3607 & 0.769 & 0.640 & 96 & 93 \\
\hline 6 & 0.3614 & 0.3605 & 0.548 & 0.661 & 96 & 99 \\
\hline $\begin{array}{l}\text { Average values } \\
\text { after wear }\end{array}$ & 0.3602 & 0.3607 & 0.69 & 0.68 & 95 & 93 \\
\hline \multicolumn{7}{|c|}{ Melting No. 2} \\
\hline Before wear & \multicolumn{2}{|c|}{0.362} & \multicolumn{2}{|c|}{0.59} & \multicolumn{2}{|c|}{92} \\
\hline 7 & 0.3601 & 0.3601 & 0.625 & 0.759 & 88 & 96 \\
\hline 8 & 0.3601 & 0.3599 & 0.564 & 0.575 & 86 & 92 \\
\hline 9 & 0.3600 & 0.3604 & 0.672 & 0.659 & 96 & 87 \\
\hline 10 & 0.3594 & 0.3596 & 0.632 & 0.623 & 88 & 89 \\
\hline 11 & 0.3607 & 0.3597 & 0.562 & 0.522 & 85 & 96 \\
\hline 12 & 0.3596 & 0.3596 & 0.68 & 0.69 & 86 & 82 \\
\hline $\begin{array}{l}\text { Average values } \\
\text { after wear }\end{array}$ & 0.359 & 0.359 & 0.62 & 0.64 & 88 & 90 \\
\hline \multicolumn{7}{|c|}{ Melting No. 3} \\
\hline Before wear & \multicolumn{2}{|c|}{0.362} & \multicolumn{2}{|c|}{0.57} & \multicolumn{2}{|c|}{94} \\
\hline 13 & 0.3611 & 0.3621 & 0.572 & 0.521 & 86 & 89 \\
\hline 14 & 0.3610 & 0.3605 & 0.707 & 0.652 & 91 & 84 \\
\hline 15 & 0.3602 & 0.3607 & 0.657 & 0.551 & 84 & 89 \\
\hline 16 & 0.3608 & 0.3619 & 0.553 & 0.793 & 76 & 80 \\
\hline 17 & 0.3607 & 0.3590 & 0.445 & 0.567 & 86 & 84 \\
\hline 18 & 0.3615 & 0.3614 & 0.699 & 0.633 & 74 & 81 \\
\hline $\begin{array}{l}\text { Average values } \\
\text { after wear }\end{array}$ & 0.360 & 0.361 & 0.60 & 0.62 & 83 & 84 \\
\hline
\end{tabular}

crohardness of the matrix, austenite-carbide eutectic and total hardness that occur in chromium-manganese alloys in the cast state and in the process of wear by friction at different loads have been studied. 
3. It is found that wear by friction at different loads leads to

- stabilization of austenite that does not undergo phase transformations. Traces of deformation in the form of shear lines are observed in the areas of austenite.

- increase of microhardness of matrix and austenitic-carbide eutectic of all experimental alloys.

4. Using X-ray diffraction analysis, the change of phase composition in the process of friction wear in chromium-manganese alloys in the cast state was found. Phase and structural transformations that occur in the process of wear by friction at different loads are associated with the redistribution of alloying elements between the phases and structural components of the experimental alloys.

5 . It is shown that the high wear resistance of chromium-manganese alloy 3 is due to the high microhardness of the matrix, austeniticcarbide eutectic based on $\mathrm{Me}_{7} \mathrm{C}_{3}$ carbide and is determined by the degree of doping and shape parameter of eutectic carbide, as well as deformation-phase transformations.

\section{REFERENCES}

1. F. P. Bowden, The Friction and Lubrication of Solids (Eds. F. P. Bowden and D. M. Tabor) (Moscow: Mashinostroenie: 1968), p. 543 (in Russian).

2. M. N. Brykov, V. G. Yefremenko, and A. V. Yefremenko, Iznosostoykost Staley i Chugunov pri Abrazivnom Iznashivanii [Abrasion Resistance of Steels and Cast Irons] (Ed. D. S. Grin) (Kherson: 2014), p. 364 (in Russian).

3. I. I. Tsypin, Belye Iznosostoikie Chuguny. Struktura i Svoystva [Wear Resistant White Cast Irons. Structure and Characteristics] (Ed. I. I. Tsypin) (Moscow: Metallurgiya: 1983), p. 176 (in Russian).

4. V.P. Gavriliuk, Abrazivostoykie Vysokokhromistye Chuguny: Monografiya [Abrasion-Resistant High-Chromium Cast Irons: Monograph] (Eds. V. P. Gavriliuk, V. I. Tikhonovich, I. A. Shalevskaia, and Yu. I. Gutko) (Luhansk: 2010), p.141 (in Russian).

5. L. S. Malinov, Povyshenie Iznosostoykosti Staley i Chugunov za Schet Polucheniya $v$ Ikh Structure Metastabilnogo Austenita i Realizatsii Effekta Samozakalki pri Nagruzhenii [Increasing the Wear Resistance of Steels and Cast Irons Due to the Production of Metastable Austenite in Their Structure and the Implementation of the Self-Quenching Effect Under Loading] (Eds. L. S. Malinov and V.L. Malinov) (Metall i Lityo Ukrainy, 2001, Nos. 1-2), p. 8 (in Russian).

6. A. P. Cheiliakh, Ekonomnolegirovannye Metastabilnye Splavy $i$ Uprochnyayushchie Tekhnologii [Economically Alloyed Metastable Alloys and Hardening Technologies] (Kharkiv: National Scientific Center 'Kharkiv Institute of Physics and Technology': 2003), p.212 (in Russian).

7. V. Z. Kutsova, Formirovanie Nanostrukturnoy Matritsy $v$ Vysokokhromistykh Chugunakh Putem Termicheskoy Obrabotki [Formation of a Nanostructured Matrix in High-Chromium Cast Irons by Heat Treatment] (Eds. V. Z. Kutsova, L. I. Markashova, M. A. Kovzel et al.) (Stroitelstvo, Materialovedenie, 
Mashinostroenie, 2007, Iss. 43), p. 229 (in Russian).

8. Yu. M. Koval, V. Z. Kutsova, M. A. Kovzel, and P. Yu. Shvets, Progress in Physics of Metals, 21, No. 2: 180 (2020).

9. V. Z. Kutsova, M. A. Kovzel, P. U. Shvets, A. V. Grebeneva, and V. V. Prutchykov, Metallofiz. Noveishie Tekhnol., 40, No. 4: 551 (2018).

10. V. Z. Kutsova, M. A. Kovzel, A. V. Grebeneva, I. V. Ratnikova, and O. A. Velichko, Metallurgical and Mining Industry, No. 9: 1084 (2015).

11. V. I. Dvoruk, Pretsyziynyy Vymiriyuvach Liniynoho Znosu Mekhanichnykh Trybosystem dlya Vyprobuvalnoyi Mashyny 2070 CMT-1 [Precision Linear Wear Meter for Mechanical Tribosystems for a Test Machine 2070 CMT-1] (Eds. V. I. Dvoruk and M. V. Matrosov) (Problemy Tertya ta Znoshuvannya: Nauk.-Tekn. Zb., Kyiv, NAU-Druk, 2008: Iss. 50), p. 44 (in Ukrainian).

12. S. A. Saltykov, Sterometricheskaya Metallografiya [Stereometric Metallography] (Moscow: Metallurgiya: 1970), p. 375 (in Russian).

13. F. R. Wilson and R. A. Harding, BCIRA Journal, 32: 318 (1984).

14. A. M. Nesterenko, V.Z. Kutsova, and M. A. Kovzel, Metallofiz. Noveishie Tekhol., No. 1: 99 (2003) (in Russian).

15. G. V. Samsonov and I. M. Vinnitskii, Tugoplavkie Soedineniya [Refractory Compounds] (Moscow: Metallurgiya: 1976), p. 560 (in Russian),

16. E. Gudremon, Spetsialnye Stali [Special Steels] (Moscow: Metallurgiya: 1959), vol. 1, p. 952 (in Russian).

17. V.S. Popov, N. N. Brykov, N. S. Dmitrichenko, and P. G. Pristupa, Dolgovechnost Oborudovaniya Ogneupornogo Proizvodstva [Durability of Refractory Equipment] (Moscow: Metallurgiya: 1977), p. 233 (in Russian).

18. Yu. G. Bobro, Legirovannye Chuguny [Alloy Cast Irons] (Moscow: Metallurgiya: 1976), p. 287 (in Russian).

19. K. P. Bunin and Yu. N. Taran, Stroenie Chuguna [Cast Iron Structure] (Moscow: Metallurgiya: 1972), p.160 (in Russian).

20. V. Z. Kutsova, M. A. Kovzel, A. V. Grebeneva, I. V. Ratnikova, and O. O. Velichko, Metallurgicheskaya i Gornorudnaya Promyshlennost, No. 3 (294): 45 (2015) (in Russian).

21. V. Z. Kutsova, M. A. Kovzel, A. V. Grebeneva, P. Yu. Shvets, A. Zyska, and B. Koczurkiewicz, Structure and Mechanical Properties of Chrome-Manganese Cast Irons in the Cast State (New Technologies and Achievements in Metallurgy, Material Engineering and Production Engineering. A Collective Monograph, Czestochowa, 2016: No. 56), p. 147. 